Article

\title{
Effects of Shoot Size and Genotype on Energy Properties of Poplar Biomass in Short Rotation Crops
}

\author{
Cristina Eimil-Fraga ${ }^{1}$, Xurxo Proupín-Castiñeiras ${ }^{2}{ }^{\mathbb{C}}$, Jose Antonio Rodríguez-Añón ${ }^{2} \mathbb{C}$ and \\ Roque Rodríguez-Soalleiro ${ }^{1, *}$ \\ 1 Unit of Sustainable Forest Management, University of Santiago de Compostela, 27002 Lugo, Spain; \\ cristina.eimil@usc.es \\ 2 Faculty of Physics, University of Santiago de Compostela, 15705 Santiago de Compostela, Spain; \\ xurxo.proupin@usc.es (X.P.-C.); ja.rodriguez.anon@usc.es (J.A.R.-A.) \\ * Correspondence: roque.rodriguez@usc.es
}

Received: 8 May 2019; Accepted: 27 May 2019; Published: 29 May 2019

\begin{abstract}
Eight poplar genotypes grown in a short rotation forest plantation established in an acid soil in South Europe were sampled at the age of 7 years to determine the energy properties regarding thermochemical conversion. The goal was to address the effect of selection of genotypes or shoot size at harvest on the energy quality of biomass. Between 34 and 50 biomass samples were obtained for each genotype: three disks were systematically sampled along the stem and were pooled together with a subsample of leafless branches representative of the biomass share of this component. Several energy properties were determined: higher calorific value, net calorific value, fresh moisture content, basic density, ash, volatile matter, fixed carbon content and elemental composition. Genotype had a significant effect on most of these properties, and the balsam genotypes displayed superior quality parameters and also higher biomass yield than the Euramerican genotypes. As a covariate, shoot basal diameter had a significant effect on the moisture content, basic density, ash content and on the concentrations of the elements $\mathrm{N}, \mathrm{K}, \mathrm{Ca}, \mathrm{Mg}, \mathrm{S}, \mathrm{Na}$ and $\mathrm{C}$. It was concluded that genotypes with low nutrient requirements planted at low density $\left(<8000\right.$ cuttings ha $\left.^{-1}\right)$ and harvested at a long enough rotation (7 years) produce good yields and high chip quality. Poplar short rotation crops can be grown to produce chips of A2 quality for non-industrial heating use (according to UNE-EN ISO 17225-4), able to be combusted in domestic thermal facilities of $<1$ MWth power.
\end{abstract}

Keywords: energy properties of biomass; poplar; short rotation coppice (SRC); shoot size at harvest

\section{Introduction}

Woody biomass is a renewable resource suitable for generating bioproducts and bioenergy for different applications (heat, electricity and second-generation biofuels) [1,2]. The production and management of woody biomass can potentially provide a new opportunity for the economic development of rural areas [3], involving many different productive sectors. Woody biomass can have different origins: residual forest biomass, residual agricultural biomass, residual industrial biomass and woody energy crops $[4,5]$.

The quality requirements of wood chips are regulated by a series of harmonized international standards that define the limits of technical parameters that influence their quality as a fuel [6]. The heating value (calorific value or heat of combustion) defines the energy content of a biomass fuel and is one of the most important characteristics for calculations and numerical simulations related to thermal systems [7], no matter how the biomass is used-in direct combustion or co-fired with other fuels [8]. On the other hand, the percentage of ash and its composition are some of the main properties of biomass determining the quality for combustion [9]. A large proportion of ash reduces the quality of 
fuel, impairs the contact between the fuel and the air available for combustion, lowers the combustion temperature and the efficiency of the boilers and increases the need for cleaning and maintenance.

Crops devoted specifically to producing biomass are generally fast-growing species such as poplar, and intensive treatments are applied within the framework of short rotation coppice $[1,10]$. The cost of producing such biomass is relatively high, as it includes the costs of establishing, maintaining, harvesting, transporting and processing the material; the cost of the land must also be added for the production of chipped biomass, the main product obtained [11]. The economic results are highly dependent on the conversion pathways, the energy policies of different countries and the inclusion of $\mathrm{CO}_{2}$ credits in the analysis. In Spain, the economic feasibility of implementing poplar biomass production for power generation [12] changed abruptly after the withdraw of the electrical tariffs for power generation produced using biomass energy crops as fuel.

Two main approaches should be combined in order to promote the use of biomass generated from short rotation coppice (SRC) as an energy source: (i) reducing the production cost per unit of biomass; and (ii) improving the energy properties of the woody chips to allow their use in conversion pathways that are highly demanding in terms of quality. Kauter et al. [13] reviewed the physiological background and agronomic means of increasing yield potential and fuel quality in the case of poplar and aspen (Populus genus). These researchers concluded that the choice of site, genotype and rotation length are the main factors affecting yield and quality; they recommended the use of hybrid poplar for rich soils in a 6-7 years rotation scheme and of aspen for poorer soils with longer rotations.

The balsam poplars in the section Tacamahaca are known to be less demanding in terms of nutrient and water supply or mean temperature in the vegetation period than the black poplars in the Aigeiros section [13], and they also tend to grow in dense stands. Genotypes of this group-or hybrids within groups-have been used successfully to grow SRC in suboptimal soil conditions, although the poor rooting ability of Populus deltoides as parental material should be considered for soils with high bulk density [14]. In the case of acid soils with sandy-loamy texture or occurring at high elevations, previous experience has shown that the hybrid inter-American crosses may perform better than the more site-demanding black poplar genotypes belonging to the P. deltoides $\times$ P. nigra group [15]. Although information on the yield of balsam genotypes has been produced for different areas both in Central and Northern Europe [16] and in Southern Europe [15], very little is known about the energy properties of these genotypes relative to the better known Euramerican crosses $[17,18]$.

The basal diameter of the shoots obtained depends on the planting density, the number of lateral shoots, the rotation length and the resprouting process after coppicing and plant mortality $[14,19]$. Plantation density is an important factor to be considered in SRC and has both production and economic implications, particularly during the first rotation. Several experimental and commercial plantations have been established at test densities ranging from 1000 to more than 40,000 plants ha ${ }^{-1}$ [20,21]. A range of densities within which production remains constant has been proposed, but there is a direct implication for the basal diameters obtained, with a trend of rapid elimination of the small shoots after coppice by self-thinning in the case of P. trichocarpa and P. trichocarpa $\times$ P. deltoides $[19,22]$. Studies on SRC density have dealt only marginally with issues such as the energetic quality of biomass, which is known to be related to the size of the shoots, mainly through the percentage bark [23].

The aim of the present study was to assess the importance of genotype and shoot size in relation to the energy properties of poplar biomass that are most relevant to the pathways of thermochemical conversion of woody chips. Genotypes and target shoot sizes are proposed for poplar crops established in acid soils of marginal use for growing black poplars.

\section{Materials and Methods}

\subsection{Study Site and Plantation Establishment}

The trial was established in a former extensively grazed pasture which had lain fallow for 15 years, leading to the development of a dense shrubland of woody legume species of the genera Ulex and 
Cytisus. The vegetation was crushed with a rotary chain implement and then incorporated into the soil by deep ploughing $(50 \mathrm{~cm}$ ) in the autumn before planting and tilling (in spring). Woody cuttings (of 25-cm in length) were planted manually in March 2009 in a double-row planting scheme, at a density was 8000 cuttings per ha.

The trial was located in Bóveda, Lugo, Spain (coordinates $42^{\circ} 36^{\prime} 30.50^{\prime \prime} \mathrm{N}$ and $7^{\circ} 28^{\prime} 12.72^{\prime \prime} \mathrm{W}$ ) at an elevation $365 \mathrm{~m}$, in a transition area between Atlantic and Mediterranean climates, where short rotation woody crops can provide good yields with almost no irrigation. The soils were classified as Regosols and had an $\mathrm{AB}$ profile, characterized by an upper horizon of depth $50 \mathrm{~cm}$ and rich in organic matter (3.0-5.3\% soil C), $\mathrm{pH}$ level in water of 4.9-5.9 and moderate levels of stoniness of quartzite. The percentage Al saturation of the exchange complex was very variable (4.9-69.4\%). Soil fertility can be considered low for an agricultural soil. The total $\mathrm{N}$ concentration was $0.2-0.4 \%$. Available P was only 8.5-12.4 ppm, whereas exchangeable K, Ca and $\mathrm{Mg}$ were on average 0.22, 2.1 and $0.89 \mathrm{cmol}(+) \mathrm{kg}^{-1}$, respectively.

Eight poplar genotypes were grown in the trial, three P. $\times$ euramericana (I-214, AF2 and AF6), one P. $\times$ interamericana $\times$ P. nigra (Monviso), three P. $\times$ interamericana (Unal, Beaupre and Raspalje) and one P. trichocarpa (Trichobel).

The crop management can be considered extensive, as fertilizer was only applied one year after planting: $240 \mathrm{~kg} \mathrm{ha}^{-1}$ of a soluble NPK complex 15/15/15 + $400 \mathrm{~kg} \mathrm{ha}^{-1}$ of granulated limestone. Mechanical and chemical (glyphosate) weed control was necessarily more intensive.

\subsection{Biomass Sampling}

All of the trees were harvested to determine the biomass yield at an age of 7 years. The crop was then in its first rotation, with roots the same age as the shoots. All the dominant shoots in each stool were measured: basal diameter at a height of $10 \mathrm{~cm}(\mathrm{~d})$ and total height. Destructive sampling was used to obtain samples for determining energy properties in order to cover the observed range of diameters. The number of shoots per stool was also counted.

The sampled leafless shoots were separated into stem and lateral branches, and the fresh weight of each fraction was obtained in order to determine the proportion of branches. Wood with bark was sampled by removal of three disks along the stem, at relative heights of $0.15,0.33$ and 0.75 . Branches were sampled at random along the canopy, considering the same share obtained for the total weight. All woody components (bark, wood and branches) were pooled together, as these components are used to produce chips after harvesting.

The samples were transported to the laboratory. Each disk was weighed and the volume was determined by immersion in water. The samples were then pooled and dried in an oven at $65^{\circ} \mathrm{C}$ until constant weight, for calculation of the moisture content. Finally, the pooled samples were milled.

\subsection{Determination of Energy Properties}

The samples were used to characterize the energy properties of each genotype for the range of diameters measured, and the fresh moisture content, basic density, higher heating value, proximate composition (ash, volatile matter and fixed carbon) and ultimate elemental composition $(\mathrm{C}, \mathrm{N}, \mathrm{H}, \mathrm{Na}$, $\mathrm{K}, \mathrm{Ca}, \mathrm{Mg}, \mathrm{S}, \mathrm{Cl}, \mathrm{Al}$ and $\mathrm{Fe}$ ) were determined.

The green biomass moisture content was determined prior to grinding by drying a subsample of biomass for $72 \mathrm{~h}$ until constant weight, expressed on a wet basis (W, \%). The basic density ( $\rho$ ) was obtained by dividing the dry weight of the disks by their saturated volume, which was obtained by immersion. The basic density of each sample was obtained with a weighted average of the values calculated for each disk. A combined sample of chipped biomass per genotype was placed for air-drying for 4 months to determine the average humidity level at the boiler.

The higher calorific value (dry basis) $\left(\mathrm{HHV}_{0}\right)$ was determined experimentally by combustion of a subsample of $0.5 \mathrm{~g}$ of the ground biomass in a bomb calorimeter (IKA C5000) under an oxygen 
atmosphere (30 atm) [24,25]. The lower heating value at the moisture content of chips feeding the boiler $\left(\mathrm{LHV}_{\mathrm{W}}\right)$ was calculated from $\mathrm{HHV}_{0}$ using the equation:

$$
\mathrm{LHV}_{\mathrm{w}}=\mathrm{HHV}_{0} \cdot(1-\mathrm{W} / 100)-24.42 \cdot(\mathrm{W}-9 \mathrm{H})
$$

where $\mathrm{H}$ is the percentage hydrogen in the dry sample and $\mathrm{W}$ refers to the moisture content (wet basis) of the chips as boiler feedstock.

Regarding the proximate composition, the dry samples were used to determine the ash component (A) in a furnace at $550{ }^{\circ} \mathrm{C}$, following the [26] standards. The volatile matter (VS) was determined by application of the [27] standards and calcination of the samples in an oven at $900{ }^{\circ} \mathrm{C}$. The fixed carbon (FC) was obtained by difference.

Elements were analyzed in stem and branch samples. The plant material was dried at $65^{\circ} \mathrm{C}$ and milled to pass through a $0.5 \mathrm{~mm}$ sieve. Total N, C and $\mathrm{H}$ were analyzed by combustion in a LECO CNS-2000 autoanalyser [28]. The plant material was digested with $\mathrm{HNO}_{3}, \mathrm{HF}$ and $\mathrm{H}_{2} \mathrm{O}_{2}$ in a microwave oven, and the concentrations of $\mathrm{B}, \mathrm{Na}, \mathrm{Mg}, \mathrm{Al}, \mathrm{P}, \mathrm{S}, \mathrm{Cl}, \mathrm{K}, \mathrm{Ca}, \mathrm{Mn}, \mathrm{Fe}, \mathrm{Cu}, \mathrm{Zn}, \mathrm{Mo}$ and $\mathrm{Si}$ were determined by ICP-MS $[29,30]$. S was also determined by combustion, for purposes of comparison.

\subsection{Statistical Analysis}

Analysis of covariance (ANCOVA) was performed to evaluate the effect of the genotypes on the energy properties of biomass, considering the basal diameter as a covariate. Several of the energy variables had to be transformed $(\arcsin \sqrt{\mathrm{x}})$ to ensure a normal distribution, particularly for those measured as percentages (W, A, vs. and FC). Because the sample size of each genotype was slightly different, a generalized linear model procedure $(\mathrm{glm})$ was used. When significant differences $(p<0.05)$ were indicated, Tukey's test was used to compare the mean values. All analyses were performed using the R statistical package [31].

\section{Results}

\subsection{Biometric Characteristics of the Sampled Trees}

Table 1 shows the main biometric characteristics of the shoots sampled. The number of shoots per stool is close to one, as the plot was studied after the (single stem) first rotation. The range of diameters broadly covers the variability in size found in a short rotation poplar, with some differences observed in the average basal diameters of genotypes in parallel to differences in yields. The average height of the dominant shoots ranged between $3.6 \mathrm{~m}$ to $5.7 \mathrm{~m}$, again with taller shoots in the most productive genotypes.

Regarding the proportion of branches, a high variability of values was found for each genotype, and therefore there were no significant differences in relation to genotype. Nonetheless, two balsam genotypes (Raspalje and Trichobel) combined good productivity with a small proportion of branches in the aboveground biomass.

Figure 1 shows the green weight of both fractions considered in sampling: branches and twigs, and the stem, both with bark. The share of branches and twigs relative to the leafless aboveground biomass was significantly correlated with diameter for all the genotypes, except Trichobel, although the variation was very broad. Thus, for $\mathrm{d}<40 \mathrm{~mm}$, the confidence interval for the branch and twig share at $p=0.95$ was $(8-32 \%)$ and for $\mathrm{d}>70 \mathrm{~mm}$, the interval was (10-40\%). These results are important for discussing the effects of the share of biomass components on energy properties. 
Table 1. Dendrometric information of the samples and total yield of each genotype. $\mathrm{N}$ stands for number of shoots per stool. H refers to the height of the dominant shoot in the stool. D refers to basal diameter. $\mathrm{Y}$ is yield of first rotation. PB is the proportion of branches. Average value and range for basal diameter and proportion of branches.

\begin{tabular}{ccccccc}
\hline Genotype & Sample Size $\mathbf{( n )}$ & $\mathbf{N}$ & $\mathbf{H}(\mathbf{m})$ & $\mathbf{D}(\mathbf{m m})$ & $\mathbf{Y}\left(\mathbf{M g ~ h a}^{\mathbf{- 1})}\right.$ & $\mathbf{P B} \mathbf{( \% )}$ \\
\hline AF2 & 40 & $1.19(0.03)$ & 4.0 & $44.9(22.4-91.6)$ & 5.9 & $23.7(6.8-34.7)$ \\
AF6 & 40 & $1.41(0.05)$ & 4.2 & $46.3(24.4-76.6)$ & 8.0 & $23.0(10.5-36.4)$ \\
BEAUPRÉ & 40 & $1.10(0.02)$ & 4.6 & $50.7(20.3-79.9)$ & 21.5 & $28.0(13.8-38.2)$ \\
I-214 & 30 & $1.58(0.05)$ & 4.8 & $50.2(26.1-81.3)$ & 20.7 & $23.5(15.4-41.7)$ \\
MONVISO & 40 & $1.21(0.03)$ & 3.6 & $37.7(19.2-55.1)$ & 6.5 & $24.5(16.6-33.5)$ \\
RASPALJE & 50 & $1.05(0.01)$ & 4.7 & $47.3(23.5-79.1)$ & 21.7 & $21.9(14.6-33.6)$ \\
TRICHOBEL & 40 & $1.01(0.01)$ & 5.7 & $54.5(20.6-86.1)$ & 27.5 & $18.9(7.7-25.4)$ \\
UNAL & 34 & $1.04(0.01)$ & 4.3 & $47.4(20.4-73.9)$ & 13.8 & $25.7(13.1-37.1)$ \\
\hline
\end{tabular}

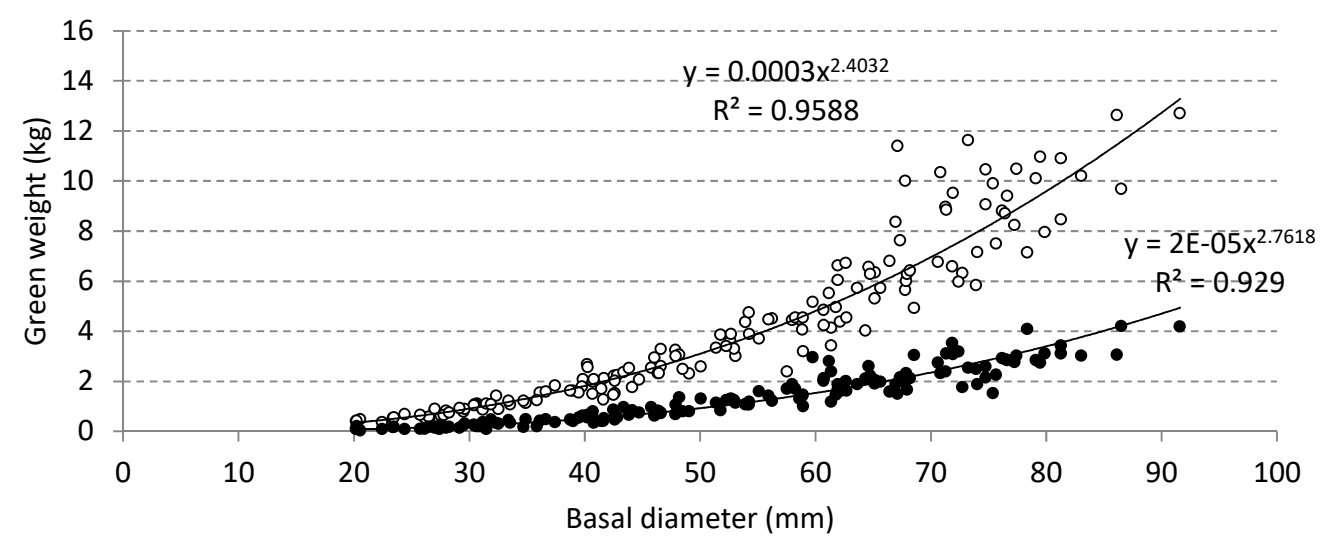

Figure 1. Green weight of the stem (white dots) and the branches and twigs (black dots) of the samples. The equations show the allometric fit of the green weight, considering the basal diameter $(\mathrm{d}, \mathrm{mm})$ as an explanatory variable.

\subsection{Calorific Values and Proximate Composition}

The results of the ANCOVA and the descriptive statistics for the first set of energy properties for the eight genotypes pooled together are shown in Table 2. The variables showing the highest coefficient of variation were A $(19.5 \%), \mathrm{W}(7.8 \%), \mathrm{FC}(9.6 \%)$ and $\rho(7.3 \%)$. The least dispersed variables were vs. $(1.5 \%)$ and, particularly, $\mathrm{HHV}_{0}(1 \%)$. The lower heating value was very variable $(\mathrm{CV}=3 \%)$.

The ANCOVA revealed a highly significant effect of the genotype for all the energy properties. The effect, although significant, was relatively low for $\mathrm{HHV}_{0}$. The lower heating value $\mathrm{LHV}_{\mathrm{W}}$ was more strongly dependent on the genotype than the dry higher heating value. The covariate basal diameter had a significant effect on ash content (negative), green moisture content (positive) and, particularly, basic density (negative relationship).

Figure 2 shows the average heating values and standard errors for each genotype. These results show that although the $\mathrm{HHV}_{0}$ was not very variable, the differences between genotypes were significant. These differences were much clearer in the case of $\mathrm{LHV}_{\mathrm{W}}$ because of the additional effect of the variation in hydrogen content and moisture content between genotypes. The Unal, Trichobel and Beaupré genotypes ranked highly for both $\mathrm{HHV}_{0}$ and $\mathrm{LHV}_{\mathrm{W}}$.

The differences in basic density and moisture content between clones are illustrated in Figure 3. The Unal and Raspalje genotypes yielded the highest wood density, whereas the moisture contents of the Unal, Trichobel and Beaupré genotypes were low, which is an advantage for transportation and facilitates further drying of the chips. 
Table 2. Results of the ANCOVA and descriptive statistics for the energy properties evaluated. G refers to genotype effect. SD stands for standard deviation.

\begin{tabular}{ccccccccc}
\hline Variable & Unit & G. Effect $(p$ Level $)$ & d Effect $(p$ Level $)$ & Average & SD & Minimum & Maximum & Typical Values * \\
\hline $\mathrm{D}$ & $\mathrm{Mm}$ & & - & 47.3 & 14.8 & 19.2 & 91.6 & - \\
$\mathrm{W}$ & $(\%)$ & $<0.0001$ & 0.004 & 56.0 & 4.4 & 36.8 & 67.5 & - \\
$\mathrm{P}$ & $\mathrm{kg} \cdot \mathrm{dm}^{-3}$ & $<0.0001$ & $<0.0001$ & 0.41 & 0.03 & 0.36 & 0.51 & - \\
$\mathrm{A}$ & $(\%)$ & $<0.0001$ & 0.0128 & 1.28 & 0.25 & 0.56 & 2.03 & 2.0 \\
$\mathrm{VS}$ & $(\%)$ & $<0.0001$ & - & 86.7 & 1.3 & 82.4 & 89.2 & - \\
$\mathrm{FC}$ & $(\%)$ & $<0.0001$ & - & 13.0 & 1.2 & 9.5 & 16.0 & - \\
$\mathrm{HHV} 0$ & $\mathrm{~kJ} \cdot \mathrm{kg}^{-1}$ & 0.0195 & - & 17,919 & 184 & 17,425 & 18,488 & 19,800 \\
LHVW & $\mathrm{kJ} \cdot \mathrm{kg}^{-1}$ & $<0.0001$ & 0.0165 & 14,818 & 434 & 13,715 & 16,426 & 18,400 \\
\hline
\end{tabular}

$\mathrm{d}=$ basal diameter, $\mathrm{W}=$ green moisture content, $\rho=$ basic density, $\mathrm{A}=$ ash, vs. = volatile matter, $\mathrm{FC}=$ fixed carbon, $\mathrm{HHV}_{0}=$ higher heating value, $\mathrm{LHV}_{\mathrm{w}}=$ lower heating value. ${ }^{*}$ Typical values for poplar according to [4] standard.
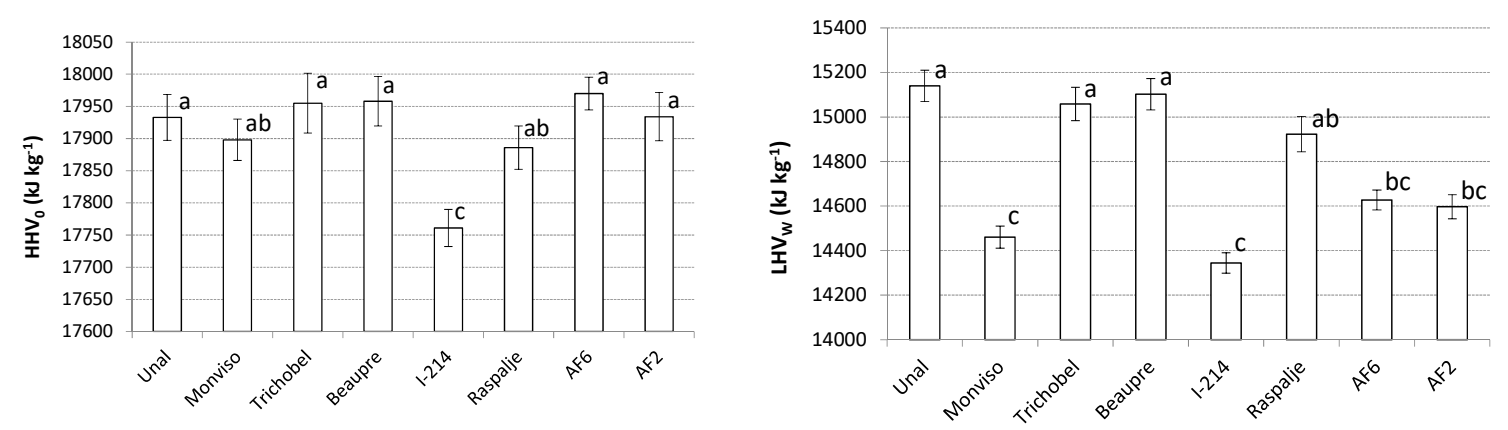

Figure 2. Mean and standard errors of the dry higher heating value $\left(\mathrm{HHV}_{0}\right.$, left $)$ and the low heating value at the boiler ( $\mathrm{LHV}_{\mathrm{W}}$, right) for the eight genotypes studied. Different letters denote significant differences (Tukey test).
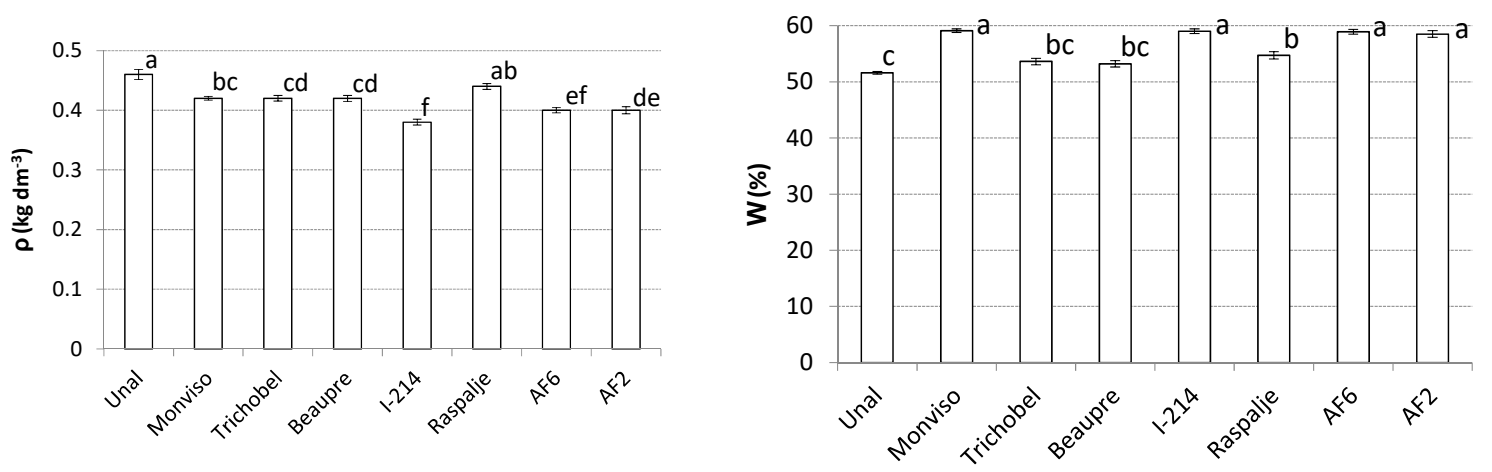

Figure 3. Mean and standard errors of the basic density $\left(\rho, \mathrm{kg} \cdot \mathrm{dm}^{-3}\right.$, left) and the fresh humidity content $(\mathrm{W}, \%$, right) for the eight genotypes studied. Different letters denote significant differences

(Tukey test).

Genotype had a highly significant effect on ash content, and the basal diameter also had a significant effect on this variable. Considering the effect of the threshold of $1.5 \%$ ashes in classifying chip quality [32], the genotypes can be grouped in three groups regarding the expected ash content: genotypes with all samples below 1.5\%, irrespective of the diameter (Beaupré, Raspalje); genotypes with less than $1.5 \%$ of ash content for $\mathrm{d}>60 \mathrm{~mm}$ (Trichobel, AF6, Unal) and genotypes with most samples above the threshold of $1.5 \%$, irrespective of the basal diameter (I-214, Monviso, AF2, see Figure 4).

With regard to the volatile content, the results clearly show the presence of two groups of genotypes, one with higher values comprising the $P$. trichocarpa and $P . \times$ interamericana genotypes and the second corresponding to the genotypes with P. nigra as parental material (Figure 5). 


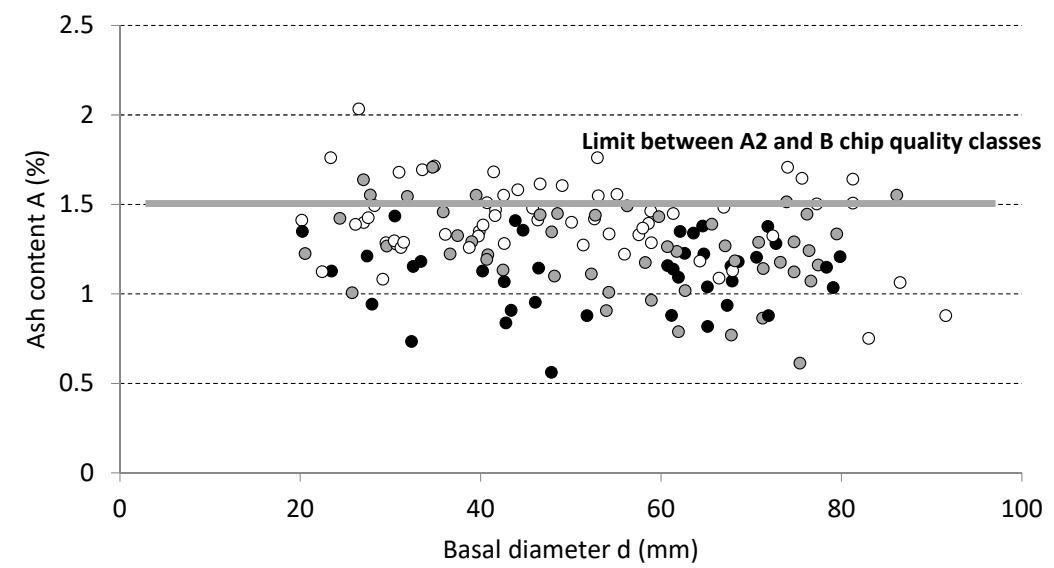

Figure 4. Relationship between ash content (\%) and basal diameter ( $\mathrm{mm}$ ) for eight poplar genotypes. Black dots represent group 1: Beaupré, Raspalje. Grey dots represent group 2: Trichobel, AF6, Unal. White dots represent group 3: I-214, Monviso, AF2.

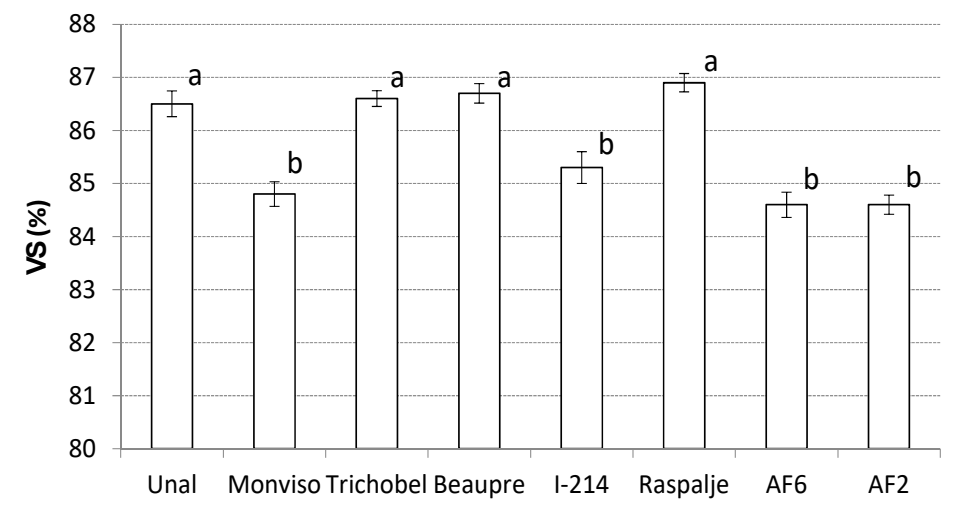

Figure 5. Mean values (and standard errors) of the volatile content (VS, \%) for the eight poplar genotypes studied. Different letters denote significant differences (Tukey test).

\subsection{Elemental Composition}

As regards the elemental composition, the ANCOVA results for the concentration of elements are shown in Table 3.

Table 3. Results of the ANCOVA and descriptive statistics for the element concentrations determined.

\begin{tabular}{|c|c|c|c|c|c|c|c|c|}
\hline Variable & Unit & $\begin{array}{c}\text { Genotype Effect } \\
(p \text { Level) }\end{array}$ & $\begin{array}{l}\text { d Effect } \\
(p \text { Level) }\end{array}$ & Average & $\begin{array}{l}\text { Standard } \\
\text { Deviation }\end{array}$ & Minimum & Maximum & $\begin{array}{l}\text { Typical } \\
\text { Values * }\end{array}$ \\
\hline $\mathrm{C}$ & $(\%)$ & $<0.0001$ & 0.0265 & 46.5 & 0.37 & 46.2 & 47.9 & 48.0 \\
\hline $\mathrm{H}$ & $(\%)$ & 0.0073 & - & 6.70 & 0.15 & 0.25 & 1.09 & 6.2 \\
\hline $\mathrm{Na}$ & $\left(\mathrm{mg} \cdot \mathrm{kg}^{-1}\right)$ & 0.0005 & 0.0058 & 37.0 & 14.3 & 19.8 & 170 & 25.0 \\
\hline K & $\left(\mathrm{mg} \cdot \mathrm{kg}^{-1}\right)$ & $<0.0001$ & $<0.0001$ & 3016 & 658 & 1472 & 4901 & 2500 \\
\hline $\mathrm{S}$ & $\left(\mathrm{mg} \cdot \mathrm{kg}^{-1}\right)$ & 0.0160 & 0.0020 & 350 & 134 & 92 & 680 & 300 \\
\hline $\mathrm{Cl}$ & $\left(\mathrm{mg} \cdot \mathrm{kg}^{-1}\right)$ & $<0.0001$ & - & 205 & 100 & 2 & 362 & $<100$ \\
\hline $\mathrm{P}$ & $\left(\mathrm{mg} \cdot \mathrm{kg}^{-1}\right)$ & $<0.0001$ & - & 500 & 199 & 212 & 1127 & 1000 \\
\hline $\mathrm{Al}$ & $\left(\mathrm{mg} \cdot \mathrm{kg}^{-1}\right)$ & $<0.0001$ & - & 41 & 21 & 2 & 105 & 10 \\
\hline $\mathrm{Fe}$ & $\left(\mathrm{mg} \cdot \mathrm{kg}^{-1}\right)$ & - & - & 18 & 14 & 2 & 116 & 30 \\
\hline
\end{tabular}

* Typical values for poplar according to [4] standard.

As expected, the mean classification for $\mathrm{HHV}_{0}$ ran parallel to the significant effect of genotypes on $\mathrm{C}$ concentration, which was highest for the Trichobel, Beaupré and Unal genotypes (Figure 6). The H concentrations were included in a narrow interval (Figure 6). 

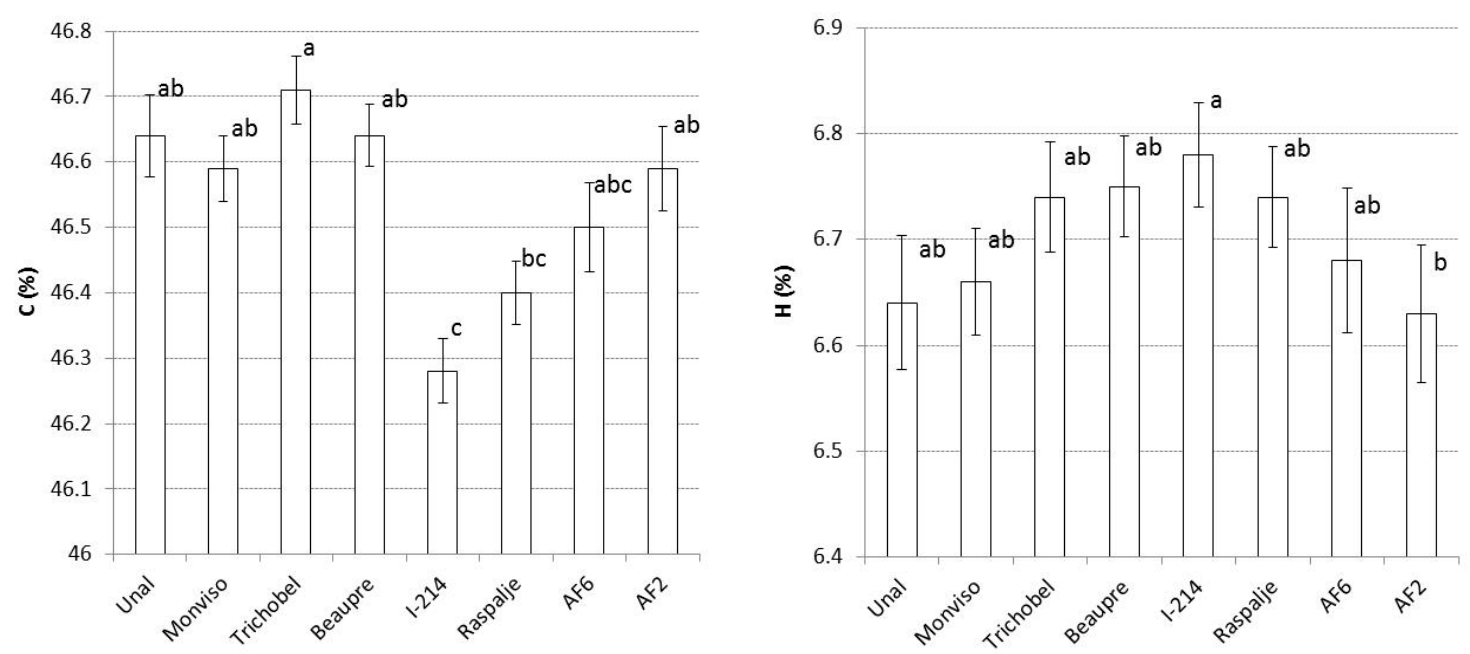

Figure 6. Mean values (and standard errors) of the C (left) and $\mathrm{H}$ (right) concentrations (\%) for the eight poplar genotypes tested. Different letters denote significant differences (Tukey test).

For the elements related to contamination hazards ( $\mathrm{N}$ and $\mathrm{S}$ ), the $\mathrm{S}$ concentrations were always lower than the threshold included in the chip standards (0.1\%) [32]. Nonetheless, Trichobel was the genotype with the lowest average mean value $(0.03 \%)$ and I-214 is the one with the highest value $(0.04 \%)$. This was not the case for $\mathrm{N}$, as some of the values obtained were close to or slightly greater than the threshold of $1 \%$ of $\mathrm{N}$ concentrations recorded for the standards [32]. The genotype had a strong effect on $\mathrm{N}$ concentrations and the mean classification included several genotypes with high values: AF6 (0.78\%a), Monviso (0.66\%b), I-214 (0.64\%bc) and AF2 $(0.63 \% \mathrm{bc})$ (Figure 7). These four genotypes are the only ones showing several values of $[\mathrm{N}] \geq 0.9 \%$. The effect on $\mathrm{N}$ concentrations of the basal diameter as a covariate is negative and thus the values observed for $\mathrm{d}>60 \mathrm{~mm}$ were never greater than $0.8 \%$. For the clones with lowest $\mathrm{N}$ concentrations (Unal, Beaupré, Raspalje and particularly Trichobel) $p([\mathrm{~N}] \geq 0.7 \% / \mathrm{d} \geq 60 \mathrm{~mm})=0.0238$, whereas $p([\mathrm{~N}] \geq 0.7 \% / \mathrm{d}<60 \mathrm{~mm})=0.1048$.
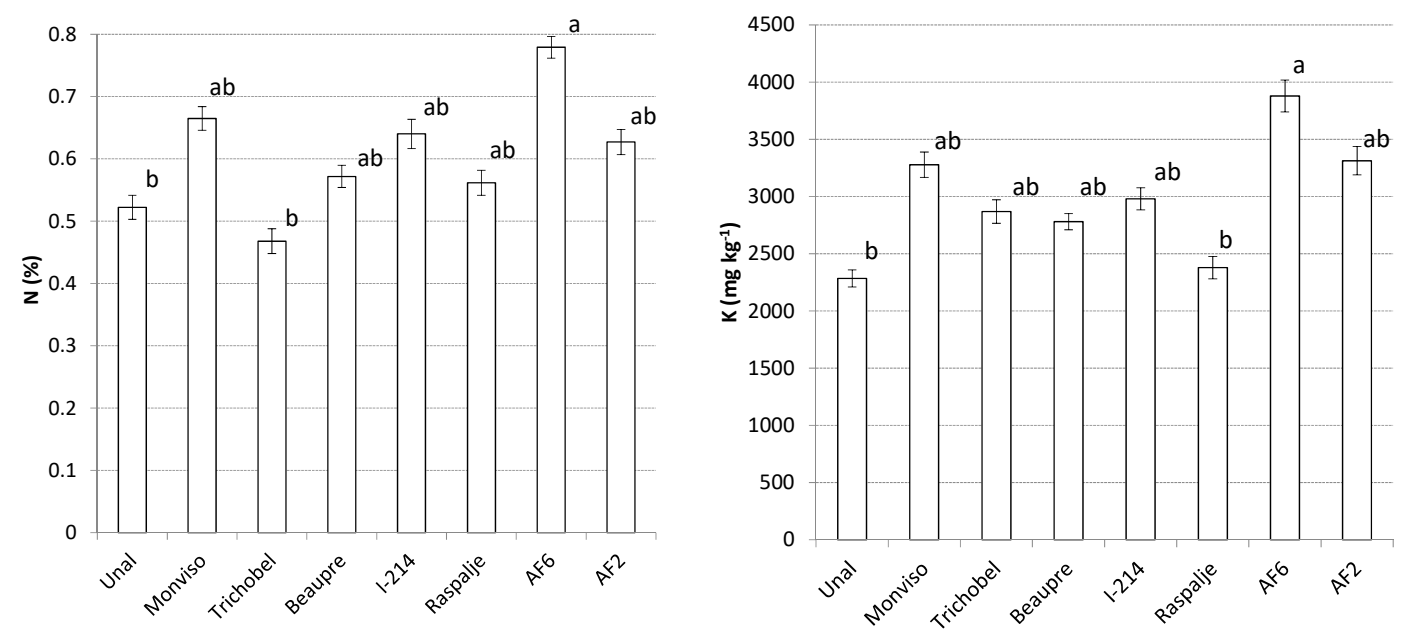

Figure 7. Mean values (and standard errors) of the $\mathrm{N}(\%$, left $)$ and $\mathrm{K}\left(\mathrm{mg} \cdot \mathrm{kg}^{-1}\right.$, right) concentrations for the eight poplar genotypes tested. Different letters denote significant differences (Tukey test).

One group of elements was directly related to the processes of corrosion, fouling and slagging. In the case of $\mathrm{Cl}$, both the mean and maximum values recorded were well below the threshold included in the standards $(0.05 \%)$ [32]. The standards do not include threshold values for the alkaline metals, $\mathrm{K}$ or $\mathrm{Na}$, even although these elements can cause fouling and slagging in boilers. The results obtained show low levels of these elements and a very significant effect of the genotype on $[\mathrm{K}]$, as the highest 
values again corresponded to four genotypes belonging to the black poplar group: AF2, AF6, Monviso and I-214 (Figure 7). Similar results were obtained for the alkaline and alkaline earth metal elements.

No significant differences between genotypes were found for $\mathrm{Mn}, \mathrm{Zn}, \mathrm{Cu}, \mathrm{Mo}$ or $\mathrm{Si}$. The mean concentrations of these elements were low: $\mathrm{Mn}, 25 \mathrm{ppm}(\mathrm{sd}=15.3) ; \mathrm{Zn}, 36 \mathrm{ppm}(\mathrm{sd}=13.5) ; \mathrm{Cu}$, $1.84 \mathrm{ppm}(\mathrm{sd}=0.83) ; \mathrm{Mo}, 0.25(\mathrm{sd}=0.8)$ and $\mathrm{Si}, 45 \mathrm{ppm}(\mathrm{sd}=4.1)$. The concentrations were well below the standard limits for $\mathrm{Cu}$ and $\mathrm{Zn}$.

\section{Discussion}

\subsection{Energy Properties and Biomass Conversion Pathways}

The current technology of harvesting short rotation poplar crops entails the use of bale or chip harvesters after leaf abscission [33] thus providing biomass without prior debarking. The shoots harvested have small diameters and include a mixture of stem and lateral branches [34], the biomass fraction analyzed in the current study. Such woody lignocellulosic biomass has several pathways of thermochemical conversion with the corresponding optimal biomass properties (Table 4). The total energy available or extractable is the same (HHV) regardless of the pathway followed [35], and many energy properties are required for all these conversions, although the thresholds may be different.

Table 4. Optimal biomass properties for thermochemical conversion pathways of biomass of relevance at present, as reported in previously published studies.

\begin{tabular}{|c|c|c|}
\hline Conversion Pathway & Optimal Biomass Properties & References \\
\hline $\begin{array}{l}\text { Combustion in domestic thermal } \\
\text { facilities, }<1 \mathrm{MWth}\end{array}$ & $\begin{array}{c}\text { Very low ash }(<1.5 \%) \text {, low } \mathrm{W}(<25 \text { or } 35 \%) \text {, very high } \\
\text { VS, very low alkali, low } \mathrm{N} \text { and } \mathrm{S}\end{array}$ & {$[23,36]$} \\
\hline $\begin{array}{l}\text { Combustion in CHP industrial } \\
\text { facilities, }>1 \mathrm{MWth}\end{array}$ & $\begin{array}{l}\text { Low ash }(<3 \text { or } 5 \%) \text {, medium-low W }(<50 \%) \text {, high VS, } \\
\text { low alkali }\end{array}$ & {$[9,35]$} \\
\hline $\begin{array}{l}\text { Gasification (downdraft of } \\
\text { fluidized bed) }\end{array}$ & $\begin{array}{c}\text { Low ash }(<5 \%) \text {, very low } \mathrm{W}(<15 \% \text {, dryer }) \text {, limited } \\
\text { particle size, high VS }\end{array}$ & {$[37,38]$} \\
\hline Slow pyrolysis to biochar & $\begin{array}{c}\text { Low W }(<30 \%) \text {, high C and nutrient content, low } \\
\text { trace elements, high FC }\end{array}$ & {$[39,40]$} \\
\hline Fast pyrolysis to bio-oil & $\begin{array}{l}\text { Very low ash }(<2.5 \%) \text {, feed grinded to very small } \\
\text { particle size }(2-6 \mathrm{~mm}) \text {, very low } \mathrm{W}(<10 \% \text {, dryer }) \text {, } \\
\text { low } \mathrm{N}, \mathrm{S} \text { and trace elements }\end{array}$ & {$[41,42]$} \\
\hline
\end{tabular}

Production of lignocellulosic biomass from dedicated woody crops costs more per unit than the residual biomass obtained from forest biomass, forest residues or the grading of forest logs (tops or small diameter logs). For poplar SRC in southern Spain, San Miguel et al. [33] reported production costs actualized at the end of the cultivation of $7.3 € / G J$ for the chipping alternative, concluding that a biomass supply chain for electricity production was not economically viable. The production target for these crops should be the quality levels that yield the highest prices in the market. This is the case with woody chips for domestic boilers, which typically reach prices of 100 to $125 € / t$. We must consider that only the two first conversion pathways included in Table 4 have a current real market for the wood chips produced.

In the present study, the slight variations in the HHV values of the samples are directly derived from some differences in the elemental composition of the biomass. Among the models proposed for estimating the HHV values, the model proposed in [43] $\left(\mathrm{HHV}\left(\mathrm{MJ} \cdot \mathrm{kg}^{-1}\right)=-0.763+0.301 \mathrm{C}+0.0525 \mathrm{H}\right.$ $+0.0064 \mathrm{O}$ ) fits reasonably well to our data, with a slight tendency to underestimate the values, with an average relative error of $4.9 \%$. As a result of the combined effect of moisture content after drying and $\mathrm{H}$ content in the genotypes studied, the $\mathrm{LHV}_{\mathrm{W}}$ was $5.5 \%$ higher in the best performing genotype (AF6) than in the poorest performing genotype (I-214). The values of $\mathrm{HHV}_{0}$ and $\mathrm{LHV}_{\mathrm{w}}$ are lower than the typical values established for poplar in the [4] standard (Table 2) and they are below the results obtained in other studies with SRC poplar [18,44-46]. 
Regarding the ash content, the threshold of $\mathrm{A}=1.5$ is particularly important, as this is the value considered for the [33] standard for separating the A2 and B quality classes of chips for non-industrial heating use. Most companies that produce wood chip boilers for low-medium power $(<1.5 \mathrm{MW})$ require the fuel used to be A1 or A2. The results of this study clearly show that some of the genotypes, particularly if managed to produce shoots of more than $60 \mathrm{~mm}$ on average, would produce chips classifiable as A2 quality. The ash content in poplar has been reported by several authors and varied between 1.30 and $4.10 \%$ depending on the genotypes. In general, the black poplars present a higher ash content than balsam poplar (Figure 8). The range of ash percentages found in the present study is considerably lower than reported in other studies. Similar results have been found by $[47,48]$ in hybrid poplar, but higher ones are the rule [49-51] (Figure 8). However, none of the genotypes in this study would produce A1 chips $(\mathrm{A}<1 \%)$.

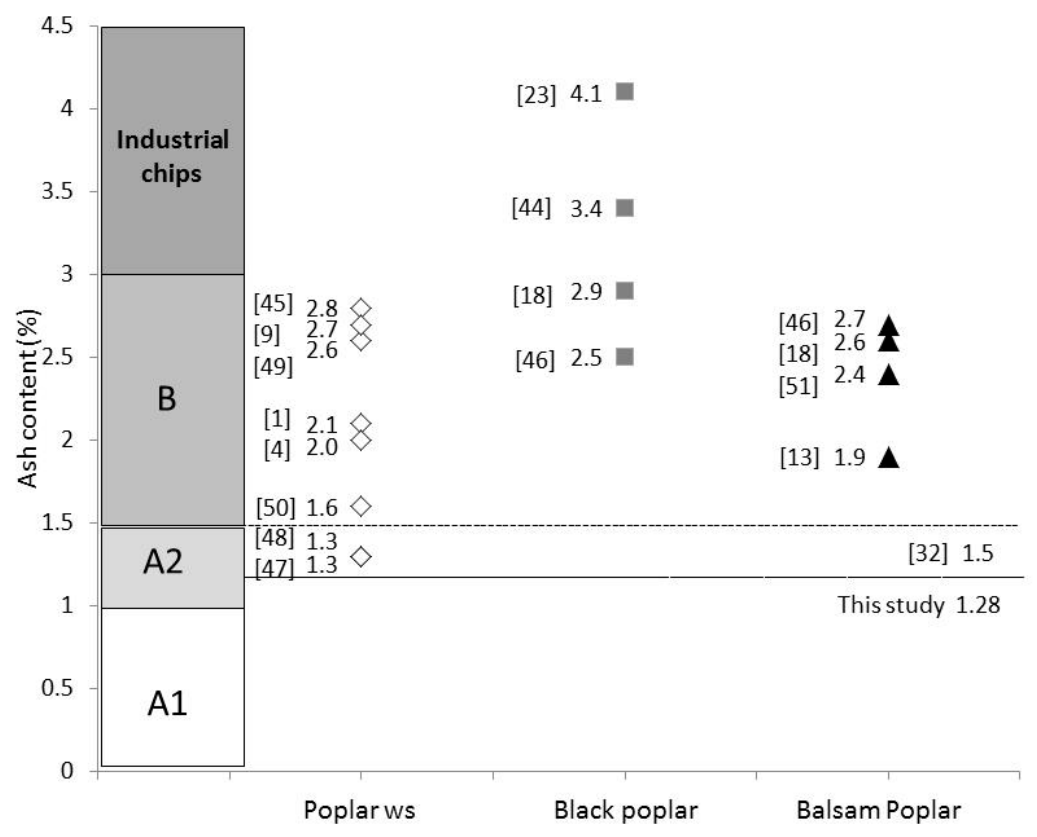

Figure 8. Values of ash content (\%) found by several authors for different poplar genotypes. $\diamond$ represents poplar without group specification (poplar ws); $\square$ grey square represent the black poplar group and black triangle represent balsam poplars. The continued line represent the values of this study and the dotted line, the threshold for the A2 quality.

The basic density of the biomass has a direct effect into the bulk density of chips expected. The basal diameter was significantly and negatively related to $\rho$, and the density values decreased from reference levels of $0.43 \mathrm{~kg} \cdot \mathrm{dm}^{-3}$ for $\mathrm{d}=20 \mathrm{~mm}$ to $0.38 \mathrm{~kg} \cdot \mathrm{dm}^{-3}$ for $\mathrm{d}=90 \mathrm{~mm}$. This implies a reduction of $13 \%$, which has consequences for transport and storage, also determining energy density. If we translate these figures into bulk density (BD), considering the average $\mathrm{W}$ as chips received $(22 \%)$ and a ratio of solid/apparent volume of chips of 0.35, the BD150 level would decrease from 193 to $170 \mathrm{~kg} \cdot \mathrm{m}^{-3}$, thus ensuring the minimum level for a quality classification of A2 using the [32] standard.

\subsection{Approaches to Improving the Energy Properties of SRC Poplar Chips}

The results of this study demonstrate that poplar genotypes belonging to the balsam poplar group (botanical section Tacamahaca) or with a parent in this group (interamerican hybrids) produce woody biomass of higher quality than the black poplar genotypes (section Aegeiros) or the genotypes with a high proportion of these genes (including the Euroamerican clones). This seems to be particularly true for sites characterized by acid soils rich in organic matter, as those included in this study. This aspect has only been partly addressed in previous studies, e.g., the reduced $\mathrm{N}$ concentrations reported for P. trichocarpa by [52]. 
As well as the importance of a correct choice of genotype, this study also shows that shoot size has an important effect on biomass quality. It is important to distinguish the effects of shoot size from those of shoot age. As shoots grow older, the concentrations of several elements decrease, as does the proportion of ash. This is partly the result of a reduction in the share of branches and twigs in the leafless biomass as age increases [13]. In this study, the shoots studied were 7 years old, and the improved quality of fuels for thicker diameters should be attributable to the reduction in the proportion of bark share but not to the proportion of branches and twigs. These results indicate lowering crop density as an additional agricultural strategy to increase fuel quality, as previously proposed [53]. Bark content has been found to affect the quality parameters of wood chips or woody sawdust pellets for other species [54].

Some available models for poplar SRC provide information about basal diameter depending on stool density and shoot height for the first rotation [55]. The model described a high level of variability in basal quadratic mean diameter in genotype I-214, probably because in short rotation crops, basal diameter is more directly dependent on initial stool density. This variable is important for considering not only the fuel quality and also the harvester limits and harvesting time [56]. If a target basal diameter of $6 \mathrm{~cm}$ is envisaged, use of the density diagram for poplar [55] clearly shows that the establishment density should be less than 8000 cuttings per ha for a height development similar to that observed in the present study.

The choice of initial stocking density will depend on the rotation length considered. In commercial plantations in Italy, the density (below 12,000 cuttings per ha) strongly affects productivity in the first cycle of 2 years [53]. Most authors have reported that the increased production per unit area associated with closer spacing at planting was no longer observed in short rotation poplar after a period of several years $[21,57]$. For black poplar hybrids in Spain, a stocking density of $<15,000$ cuttings per ha has been recommended taking into account the overall results of biomass production, planting costs and plantation maintenance [21]. With the results of this study and particularly for balsam poplars to be used in acid soils with rotation of 7 years, the proposed density taking into account the fuel quality parameters should be below 8000 cuttings per ha. The predicted vigorous sprouting after the first coppice $[10,58]$ would increase the shoot density and reduce the average shoot diameter at the second coppice [59] and thus an early reduction in shoot number should probably be considered if fuel quality is to be maintained.

The ash and nutrient contents obtained in this study are lower than reported for Euramerican genotypes $[18,23,55]$ and $\mathrm{Ca}$ and $\mathrm{P}$ content are also below the typical values established for poplar in the [4] standard (2014) (Table 3). This is due to the acid properties of the soils where the trial was established and also to the intrinsically low nutrient requirements of some of the clones used. Balsam genotypes show low concentrations of basic elements, but also of N. Our findings indicate that the combination of crop management to yield basal diameters above $60 \mathrm{~mm}$ and the choice of low [N] genotypes is a good combination to prevent the risk of NOx emissions. Although the yield obtained in the present study can be considered limited, the quality of the biomass produced would be higher than in Euramerican genotypes grown in optimal sites $[18,60]$. The low nutrient availability in the study site also results from a single application of fertilizer, which impairs the possible comparison of the results with previously published estimates obtained from frequently fertilized plantations.

A relevant energy property that has not been addressed in this study is the slagging risk. The potential slagging risk can be determined by analyzing ash composition-based slagging indices against ash fusion temperatures or combustion experiments [61,62]. This deficiency must be addressed and the differences in the slagging risk explored in relation to genotype and diameter in future studies.

\section{Conclusions}

Significant differences between genotypes and dependence on diameter of fuel quality were observed in this study, with balsam genotypes displaying superior quality parameters and higher biomass yield than the Euramerican genotypes. On the basis of ash content, wood chips produced 
from several genotypes could only be classified as B quality, for non-industrial use, irrespective of diameter. However, other genotypes can produce A2 quality wood chips if grown to attain basal diameters greater than $60 \mathrm{~mm}$.

Poplar genotypes with low nutrient requirements planted at low density $\left(<8000\right.$ cuttings ha $\left.^{-1}\right)$ and harvested at long enough rotation (7 years) can provide good yields and high chip quality. Poplar short rotation crops can be grown to produce chips of A2 quality, able to be combusted in domestic thermal facilities of $<1$ MWth power.

Author Contributions: C.E.-F. performed the experiments and contributed to the analysis of results and to the writing of the manuscript. X.P.-C. and J.A.R.-A. performed calorimetry experiments and contributed to the analysis of results. R.R.-S. contributed to the design and implementation of the research, to the analysis of the results and wrote the paper with input of all authors.

Funding: This work was financially supported by project RTA2014-00007-00007-C03-02, Spanish Ministry of Economy and Competitivity.

Acknowledgments: Christine Helen Francis revised the English.

Conflicts of Interest: The authors declare no conflict of interest.

\section{References}

1. McKendry, P. Energy production from biomass (part 1): Overview of biomass. Bioresour. Technol. 2002, 83, 37-46. [CrossRef]

2. Zhang, $\mathrm{X}$.; Tu, M.; Paice, M. Routes to potential bioproducts from lignocellulosic biomass lignin and hemicelluloses. Bioenergy Res. 2011, 4, 246-257. [CrossRef]

3. IEA Bioenergy. Sustainable Production of Woody Biomass for Energy; International Energy Agency: Paris, France, 2002; p. 12.

4. UNE-EN ISO 17225-1. Solid Biofuels. Fuel Specifications and Classes-Part 1: General Requirements; AENOR: Madrid, Spain, 2014; p. 62.

5. Srirangan, K.; Akawi, L.; Moo-Young, M.; Chou, C.P. Towards sustainable production of clean energy carriers from biomass resources. Appl. Energy 2012, 100, 172-186. [CrossRef]

6. Zanetti, M.; Costa, C.; Greco, R.; Grigolato, S.; Ottaviani, G.; Cavalli, R. How wood fuels' quality relates to the standards: A class-modelling approach. Energies 2017, 10, 1455. [CrossRef]

7. Sheng, C.; Azevedo, J.L.T. Estimating the higher heating value of biomass fuels from basic analysis data. Biomass Bioenergy 2005, 28, 499-507. [CrossRef]

8. Sami, M.; Annamalai, K.; Wooldridge, M. Co-firing of coal and biomass fuel blends. Prog. Energy Combust. Sci. 2001, 27, 171-214. [CrossRef]

9. Jenkins, B.M.; Baxter, L.L.; Miles, T.R., Jr.; Miles, T.R. Combustion properties of biomass. Fuel Process. Technol. 1998, 54, 17-46. [CrossRef]

10. Stanturf, J.A.; Oosten, C.V. Operational Poplar and Willow culture. In Poplars and Willows: Trees for Society and the Environment; Isebrands, J., Richardson, J., Eds.; CABI: Wallingford, UK, 2014; pp. 200-257.

11. Yemshanov, D.; McKenney, D. Fast-growing poplar plantations as a bioenergy supply source for Canada. Biomass Bioenergy 2008, 32, 185-197. [CrossRef]

12. Gasol, C.M.; Martínez, S.; Rigola, M.; Rieradevall, J.; Anton, A.; Carrasco, J.; Ciria, P.; Gabarrell, X. Feasibility assessment of poplar bioenergy systems in the Southern Europe. Renew. Sustain. Energy Rev. 2009, 13, 801-812. [CrossRef]

13. Kauter, D.; Lewandowski, L.; Claupein, W. Quantity and quality of harvestable biomass from Populus short rotation coppice for solid fuel use-A review of the physiological basis and management influences. Biomass Bioenergy 2003, 24, 411-427. [CrossRef]

14. Laureysens, I.; Pellis, A.; Willems, J.; Ceulemans, R. Growth and production of a short rotation coppice culture of poplar. III. Second rotation results. Biomass Bioenergy 2005, 29, 10-21. [CrossRef]

15. Grau, J.M.; González, F.; Montoto, J.L. Clones de chopo para una nueva populicultura de media y alta montaña. Cuadernos de la SECF 1997, 5, 183-189. 
16. Dillen, S.Y.; Djomo, S.N.; Al Afas, N.; Vanbereven, S.; Ceulemans, R. Biomass yield and energy balance of a short rotation poplar coppice with multiple clones on degraded land during 16 years. Biomass Bioenergy 2013, 56, 157-165. [CrossRef]

17. Fernández, M.J.; Ciria, P.; Barro, R.; Losada, J.; Pérez, J.; Sixto, H.; Carrasco, J.E. Quality of the biomass produced in short rotation coppices of poplar, willow, black locust and sycamore in two different Spanish locations. In Proceedings of the 21st European Biomass Conference and Exhibition, Copenhagen, Denmark, 3-7 June 2013.

18. Monedero, E.; Hernández, J.J.; Cañellas, I.; Otero, J.M.; Sixto, H. Thermochemical and physical evaluation of poplar genotypes as short rotation forestry crops for energy use. Energy Convers. Manag. 2016, 129, 131-139. [CrossRef]

19. Al Afas, N.; Marron, N.; Van Dongen, S.; Laureysens, I.; Ceulemans, R. Dynamics of biomass production in a poplar coppice culture over three rotations (11 years). Forest Ecol. Manag. 2008, 255, 1883-1891. [CrossRef]

20. Fiala, M.; Bacenetti, J.; Scaravonati, A.; Bergonzi, A. Short rotation coppice in northern Italy: Comprenhensive Sustainability. In Proceedings of the 18th European Biomass Conference and Exhibition, Lyon, France, 3-7 May 2010.

21. Cañellas, I.; Huelin, P.; Hernández, M.J.; Ciria, P.; Calvo, R.; Gea-Izquierdo, G.; Sixto, H. The effect of density on short rotation Populus sp. Plantations in the Mediterranean area. Biomass Bioenergy 2012, 46, 645-652. [CrossRef]

22. Benetka, V.; Novotná, K.; Štochlová, P. Biomass production of P. nigra clones grown in short rotation coppice systems in three different environments over four rotations. iForest 2014, 7, 233-239. [CrossRef]

23. Tharakan, P.J.; Volk, T.A.; Abrahamson, L.P.; White, E.H. Energy feedstock characteristics of willow and hybrid poplar clones at harvest age. Biomass Bioenergy 2003, 25, 571-580. [CrossRef]

24. Villanueva, M.; Proupín, J.; Rodríguez Añón, J.A.; Fraga-Grueiro, L.; Salgado, J.; Barros, N. Energetic characterization of forest biomass by calorimetry and thermal analysis. J. Therm. Anal. Calorim. 2011, 104, 61-67. [CrossRef]

25. UNE-EN ISO 18125. Solid Biofuels. Determination of Calorific Value; AENOR: Madrid, Spain, $2017 ;$ p. 71.

26. UNE-EN ISO 18122. Solid Biofuels. Determination of Ash Content; AENOR: Madrid, Spain, 2016; p. 14.

27. UNE-EN ISO 18123. Solid Biofuels. Determination of the Content of Volatile Matter; AENOR: Madrid, Spain, 2016; p. 16.

28. UNE-EN ISO 16948. Solid Biofuels. Determination of Total Content of Carbon, Hydrogen and Nitrogen; AENOR: Madrid, Spain, 2015; p. 16.

29. UNE-EN ISO 16967. Solid Biofuels. Determination of Major Elements $\mathrm{Al}, \mathrm{Ca}, \mathrm{Fe}, \mathrm{Mg}, \mathrm{P}, \mathrm{K}, \mathrm{Si}, \mathrm{Na}$ and Ti; AENOR: Madrid, Spain, 2015; p. 20.

30. UNE-EN ISO 16994. Solid Biofuels. Determination of Total Content of Sulfur and Chlorine; AENOR: Madrid, Spain, 2017; p. 18.

31. R Development Core Team. R: A Language and Environment for Statistical Computing; R Foundation for Statistical Computing: Vienna, Austria, 2013.

32. UNE-EN ISO 17225-4. Solid Biofuels. Fuel Specifications and Classes_Part 4: Wood Chips for Non-Industrial Use; AENOR: Madrid, Spain, 2014; p. 14.

33. San Miguel, G.; Corona, B.; Ruíz, D.; Landholmb, D.; Laina, R.; Tolosana, E.; Sixto, H.; Cañellas, I. Environmental, energy and economic analysis of a biomass supply chain based on a poplar short rotation coppice in Spain. J. Clean Prod. 2015, 94, 93-101. [CrossRef]

34. Spinelli, R.; Nati, C.; Magagnotti, N. Using modified foragers to harvest shortrotation poplar plantations. Biomass Bioenergy 2009, 33, 817-821. [CrossRef]

35. McKendry, P. Energy production from biomass (part 2): Conversion technologies. Bioresour. Technol. 2002, 83, 47-54. [CrossRef]

36. Obernberger, I.; Brunner, T.; Bärnthaler, G. Chemical properties of solid biofuels-significance and impact. Biomass Bioenergy 2006, 30, 973-982. [CrossRef]

37. McKendry, P. Energy production from biomass (part 3): Gasification technologies. Bioresour. Technol. 2002, 83, 55-63. [CrossRef]

38. Elder, T.; Groom, L.H. Pilot scale gasification of woody biomass. Biomass Bioenergy 2011, 35, 3522-3528. [CrossRef] 
39. Kloss, S.; Zehetner, F.; Dellantonio, A.; Hamid, R.; Ottner, F.; Liedtke, V.; Schwanninger, M.; Gerzabek, M.H.; Soja, G. Characterization of Slow Pyrolysis Biochars: Effects of Feedstocks and Pyrolysis Temperature on Biochar Properties. J. Environ. Qual. 2012, 41, 990-1000. [CrossRef]

40. Kwapinski, W.; Byrne, C.M.P.; Kryachko, E.; Wolfram, P.; Adley, C.; Leahy, J.J.; Novotny, E.H.; Hayes, M.H.B. Biochar from biomass and waste. Waste Biomass Valorization 2010, 1, 177-189. [CrossRef]

41. Bridgwater, T. Challenges and opportunities in fast pyrolysis of biomass: Part I. Johnson Matthey Technol. Rev. 2018, 62, 118-130. [CrossRef]

42. Elliott, D.C.; Hart, T.R.; Neuenschwander, G.G.; Rotness, L.J.; Zacher, A.H. Catalytic hydroprocessing of biomass fast pyrolysis bio-oil to produce hydrocarbon products. Environ. Prog. Sustain. Energy 2009, 28, 441-449. [CrossRef]

43. Jenkins, B.M.; Ebeling, J.M. Correlations of physical and chemical properties of terrestrial biomass with conversion. In Symposium Papers—Energy from Biomass and Wastes; Inst of Gas Technology: Des Plaines, IL, USA, 1985; pp. 371-403.

44. Pannacci, E.; Bartolini, S.; Covarelli, G. Evaluation of four poplar clones in a short rotation forestry in Central Italy. Ital. J. Agron. 2009, 4, 191-198. [CrossRef]

45. Díaz-Ramírez, M.; Frandsen, F.J.; Glarborg, P.; Sebastián, F.; Royo, J. Partitioning of K, Cl, S and P during combustion of poplar and brassica energy crops. Fuel 2014, 134, 209-219. [CrossRef]

46. Carmona, R.; Nuñez, T.; Alonso, M.F. Biomass yield and quality of an energy dedicated crop of poplar (Populus spp.) clones in the Mediterranean zone of Chile. Biomass Bioenergy 2015, 74, 96-102. [CrossRef]

47. Esteghlalian, A.; Hashimoto, A.G.; Fenske, J.J.; Penner, M.H. Modeling and optimization of the dilute-sufuric-acid pretreatment of corn stover, poplar and swithgrass. Bioresour. Technol. 1997, 59, 129-136. [CrossRef]

48. Brown, R.C. Biorenewable Resource. Engineering New Products from Agriculture; Iowa State Press: Iowa City, IA, USA, 2003; p. 17.

49. Du, S.; Yang, H.; Qian, K.; Wang, X.; Chen, H. Fusion and transformation properties of the inorganic components in biomass ash. Fuel 2014, 117, 1281-1287. [CrossRef]

50. Pari, L.; Ciriello, A.; Gallucci, F. Consequence of SRF poplar wood harvesting method on energy content preservation. In Proceedings of the 16th European Biomass Conference \& Exibition, Valencia, Spain, 2-6 June 2008; p. 6.

51. Bungart, R.; Hüttl, R.F. Production of biomass for energy in post-mining landscapes and nutrient dynamics. Biomass Bioenergy 2001, 20, 181-187. [CrossRef]

52. Heilman, P.E.; Stettler, R.F. Nutritional concerns in selection of black cottonwood and hybrid clones for short rotation. Can. J. For. Res. 1986, 16, 860-863. [CrossRef]

53. Bergante, S.; Facciotto, G.; Minotta, G. Identification of the main site factors and management intensity affecting the establishment of Short-Rotation-Coppices (SRC) in Northern Italy through stepwise regression analysis. Cent. Eur. J. Biol. 2010, 5, 522-530. [CrossRef]

54. Filbakk, T.; Jirjis, R.; Nurmi, J.; Høibø, O. The effect of bark content on quality parameters of Scots pine (Pinus sylvestris L.) pellets. Biomass Bioenergy 2011, 35, 3342-3349. [CrossRef]

55. Oliveira, N.; Sixto, H.; Cañellas, I.; Rodríguez Soalleiro, R.; Pérez Cruzado, C. Productivity model and reference diagram for short rotation biomass crops of poplar grown in Mediterranean environments. Biomass Bioenergy 2015, 72, 309-320. [CrossRef]

56. Fiala, M.; Bacenetti, J. Economic, energetic and environmental impact in short rotation coppice harvesting operations. Biomass Bioenergy 2012, 42, 107-113. [CrossRef]

57. De Bell, D.S.; Clendenen, G.W.; Harrington, C.A.; Zasada, J.C. Tree growth and stand development in short-rotation Populus plantings: 7-year results for two clones at three spacings. Biomass Bioenergy 1996, 11, 253-269. [CrossRef]

58. Laureysens, I.; Deraedt, W.; Ceulemans, R. Population dynamics in a 6-year-old coppice culture of poplar: II. Size variability and one-sided competition of shoots and stools. For. Ecol. Manag. 2005, 218, 115-128. [CrossRef]

59. Verlinden, M.S.; Broeckx, L.S.; Ceulemans, R. First vs. second rotation of a poplar short rotation coppice: Above-ground biomass productivity and shoot dynamics. Biomass Bioenergy 2015, 73, 174-185. [CrossRef] 
60. Hofmann-Schielle, C.; Jug, A.; Makeschin, F.; Rehfuess, K.E. Short-rotation plantations of balsam poplars, aspen and willows on former arable land in the Federal Republic of Germany. I. Site-growth relationships. For. Ecol. Manag. 1999, 121, 41-55. [CrossRef]

61. Gilbe, C.; Ö̈hman, M.; Lindström, E.; Boström, D.; Backman, R.; Samuelsson, R.; Burvall, J. Slagging characteristics during residential combustion of biomass pellets. Energy Fuels 2008, 22, 3536-3543. [CrossRef]

62. Vega-Nieva, D.J.; Ortiz Torres, L.; Míguez Tabares, J.L.; Morán, J. Measuring and Predicting the Slagging of Woody and Herbaceous Mediterranean Biomass Fuels on a Domestic Pellet Boiler. Energy Fuels 2016, 30, 1085-1095. [CrossRef]

(C) 2019 by the authors. Licensee MDPI, Basel, Switzerland. This article is an open access article distributed under the terms and conditions of the Creative Commons Attribution (CC BY) license (http://creativecommons.org/licenses/by/4.0/). 